\title{
Productivity of maize-bean intercropping in a semi-arid region of South Africa
}

\author{
M Tsubo*, E Mukhala ${ }^{\dagger}, \mathrm{HO}$ Ogindo and S Walker \\ Department of Soil, Crop and Climate Sciences, University of the Free State, PO Box 339, Bloemfontein 9300, South Africa
}

\begin{abstract}
Food shortage is known to have been caused by overpopulation, natural disasters and poor food distribution. In areas facing food insecurity, such as Africa, peasants or small-scale farmers have practised intercropping since old times. In this study, an investigation was carried out to determine whether intercropping increased production for small-scale farming in a semi-arid region (Free State, South Africa). Crop productivity of maize and bean intercropping systems was evaluated in terms of crop yield and growth. The effect of radiation and water utilisation by these systems was measured to determine their productivity. Field trials were carried out during three summer crop growing seasons (plant densities, row orientation and sowing date trials. In all growing seasons, rainfall was below normal, and air temperatures were normal. The total land equivalent ratios for yield and growth ranged between 1.06 to 1.58 and 1.38 to 1.86 respectively, showing yield and growth advantage of intercropping. Concerning radiation and water use, the intercropping of maize and beans had both radiation and water use efficiencies (RUE and WUE, respectively) as high as maize sole cropping, and intercropping RUE and WUE were greater than bean sole cropping. From these results, it has been concluded that maize-bean intercropping can be recommended to small-scale farmers in this semi-arid region.
\end{abstract}

Keywords: intercropping, land equivalent ratio, Phaseolus vulgaris, radiation use efficiency, water-use efficiency, Zea mays

\section{Introduction}

Over-population, natural disasters and food distribution and low food production are causes of food insecurity in Africa as well as other developing countries. Most African farmers are small-scale farmers. According to an FAO Report on the State of Food Insecurity in the World 2000 (FAO, 2000), about 800 million people in the developing countries do not have sufficient food. In Southern Africa, large populations are malnourished as well. The bulk of these populations reside in rural areas, with large numbers experiencing food insecurity (Van Rooyen and Sigwele, 1998). In these areas, small-scale farming plays an important role in food security. Food insecurity is increased by adverse weather conditions and droughts throughout Southern Africa. Variable rainfall is characteristic in Southern Africa, with annual rainfall varying from $100 \mathrm{~mm}$ in the arid zones to $1500 \mathrm{~mm}$ in the humid zones (Le Houérou et al., 1993). This results in high variation in the potential of natural resource-based farming. Specifically, seasonally erratic rainfall and sandy soils cause low production in many areas.

The improvement of crop productivity is the common aim of farmers and agriculturists. The key to sustainable agriculture probably lies in increased output per unit area together with arable land expansion. In terms of cropping systems, the solutions may not only involve the mechanised rotational mono-culture cropping systems used in developed countries such as North America and Western Europe, but also the poly-culture cropping system traditionally used in developing countries such as Africa and Latin America (Francis and Adipala, 1994). The main reason for using a

\footnotetext{
* To whom all correspondence should be addressed.

용+2751 401 2656; fax: +2751 401 3506; e-mail: tsubom@ @ci.uovs.ac.za Current address: Southern African Development Community, Regional Food Security Programme, PO Box 4046, Harare, Zimbabwe
}

Received 27 January 2003; accepted in revised form 22 July 2003. multiple cropping system is the fact that it involves integrating crops using space and labour more efficiently (Baldy and Stigter, 1997). Biophysical reasons include better utilisation of environmental factors, greater yield stability in variable environments and soil conservation practices. Socio-economic reasons include the magnitude of inputs and outputs and their contribution to the stabilisation of household food supply (Beets, 1982).

Intercropping, which is one type of multiple cropping system, has been practised traditionally by small-scale farmers in the tropics. In particular, cereal and legume intercropping is recognised as a common cropping system throughout tropical developing countries (Ofori and Stern, 1987). Typically, cereal crops such as maize (Zea mays), millet (Pennisetum glaucum) and sorghum (Sorghum bicolor) are dominant crop/plant species, whereas legume crops such as beans (Phaseolus vulgaris), cowpea (Vigna unguiculata), groundnut (Arachis hypogaea), pigeonpea (Cajanus cajan) and soybean (Glycine max) are the associated plant species. Generally, in Southern Africa, maize and beans are staple and supplementary crops respectively. Canopy structures and root systems of cereal crops are generally different from those of legume crops. The formative rate is comparatively greater in cereal crops than in legume crops. In cereal-legume intercropping, cereal crops form relatively higher canopy structures than legume crops and the roots of cereal crops grow to a greater depth than those of legume crops. This indicates that the component crops probably have differing spatial and temporal use of environmental resources such as radiation, water and nutrients (Willey, 1990). Therefore, this cropping system may help improve productivity of low external input farming, which depends largely on natural resources such as rainfall and soil fertility.

In developed countries, agricultural scientists, consultants and extension officers usually provide timely and proper meteorological information to farmers, but on-farm advisories in Africa are lacking (Stigter and Weiss, 1986). Small-scale farmers have practised traditional cropping techniques, such as intercropping, in 
TABLE 1

Agronomic information and experimental treatments of the field experiments

\begin{tabular}{|c|c|c|c|c|}
\hline \multicolumn{2}{|c|}{ Growing season } & $1996 / 1997$ & $1998 / 1999$ & $2000 / 2001$ \\
\hline \multicolumn{2}{|l|}{ Trial type } & Plant density trial & Row orientation trial & Sowing date trial \\
\hline Crop variety & $\begin{array}{l}\text { Maize } \\
\text { Beans }\end{array}$ & $\begin{array}{l}\text { SNK2147 (late maturity) } \\
\text { PAN127 (determinate) }\end{array}$ & $\begin{array}{l}\text { SNK2147 (late maturity) } \\
\text { PAN127 (determinate) }\end{array}$ & $\begin{array}{l}\text { PAN6804 (early maturity) } \\
\text { PAN148 (indeterminate) }\end{array}$ \\
\hline \multicolumn{2}{|c|}{ Growing period } & 20 weeks & 20 weeks & 17 weeks \\
\hline \multicolumn{2}{|c|}{ Rainfall + Irrigation } & $913 \mathrm{~mm}$ & $636 \mathrm{~mm}$ & $\begin{array}{l}255 \mathrm{~mm} \\
325 \mathrm{~mm} \\
\end{array}$ \\
\hline \multicolumn{2}{|c|}{ Basal fertilizer } & $254 \mathrm{~N}, 67 \mathrm{P}, 33 \mathrm{~K} \mathrm{~kg} \cdot \mathrm{ha}^{-1}$ & $172 \mathrm{~N}, 47 \mathrm{P}, 32 \mathrm{~K} \mathrm{~kg} \cdot \mathrm{ha}^{-1}$ & $240 \mathrm{~N}, 96 \mathrm{P}, 48 \mathrm{~K} \mathrm{~kg} \cdot \mathrm{ha}^{-1}$ \\
\hline Plant density & $\begin{array}{l}\text { Sole maize } \\
\text { Sole beans } \\
\text { Intercrop maize } \\
\text { Intercrop beans }\end{array}$ & $\begin{array}{c}2.2,4.4,6.7 \text { plants } \cdot \mathrm{m}^{-2} \\
4.2,8.3,12.5 \text { plants } \cdot \mathrm{m}^{-2} \\
2.2,4.4,6.7 \text { plants } \cdot \mathrm{m}^{-2} \\
2.1,4.2,6.3 \text { plants } \cdot \mathrm{m}^{-2}\end{array}$ & $\begin{array}{l}6.7 \text { plants } \cdot \mathrm{m}^{-2} \\
13.3 \text { plants } \cdot \mathrm{m}^{-2} \\
6.7 \text { plants } \cdot \mathrm{m}^{-2} \\
6.7 \text { plants } \cdot \mathrm{m}^{-2}\end{array}$ & $\begin{array}{c}4.0 \text { plants } \cdot \mathrm{m}^{-2} \\
10.0 \text { plants } \cdot \mathrm{m}^{-2} \\
4.0 \text { plants } \cdot \mathrm{m}^{-2} \\
10.0 \text { plants } \cdot \mathrm{m}^{-2}\end{array}$ \\
\hline \multicolumn{2}{|c|}{ Row orientation } & north-south & $\begin{array}{l}\text { north-south } \\
\text { east-west }\end{array}$ & east-west \\
\hline \multicolumn{2}{|l|}{ Sowing date } & 9 December 1996 & 24 November 1998 & $\begin{array}{l}23 \text { November } 2000 \\
11 \text { January } 2001\end{array}$ \\
\hline Row spacing & $\begin{array}{l}\text { Sole maize } \\
\text { Sole beans } \\
\text { Intercropping }\end{array}$ & $\begin{array}{c}0.75 \mathrm{~m} \\
0.40 \mathrm{~m} \\
\text { See Fig. 2a }\end{array}$ & $\begin{array}{c}1.00 \mathrm{~m} \\
0.50 \mathrm{~m} \\
\text { See Fig. } 2 \mathrm{~b}\end{array}$ & $\begin{array}{c}1.00 \mathrm{~m} \\
0.40 \mathrm{~m} \\
\text { See Fig. 2c }\end{array}$ \\
\hline \multicolumn{2}{|l|}{ Plot size } & $6 \mathrm{~m} \times 9 \mathrm{~m}$ & $10 \mathrm{~m} \times 15 \mathrm{~m}$ & $12 \mathrm{~m} \mathrm{x} 15 \mathrm{~m}$ \\
\hline \multicolumn{2}{|c|}{ Size of final harvest area } & $12-23 m^{2}$ & $15 \mathrm{~m}^{2}$ & $12-16 m^{2}$ \\
\hline
\end{tabular}

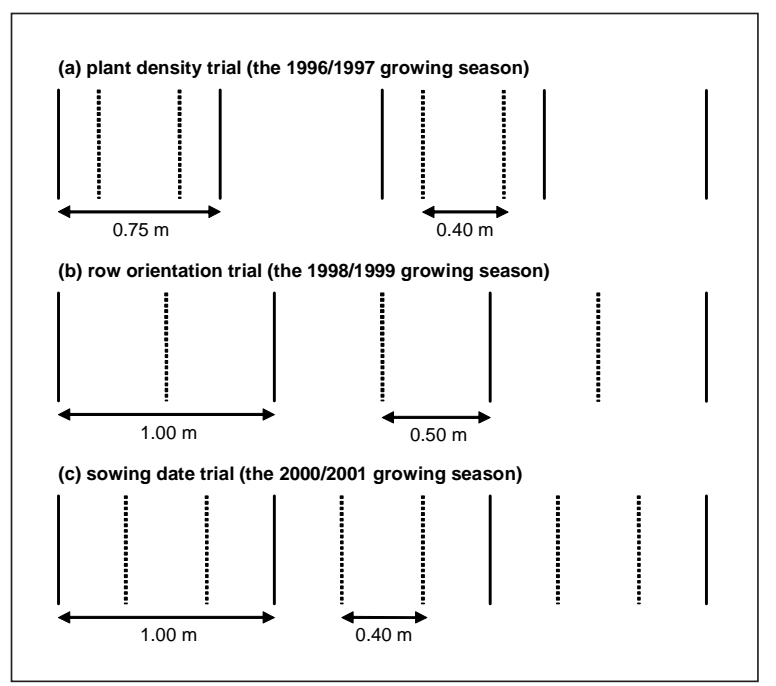

Figure 1

Crop row arrangement of intercropping systems of maize (—) and beans (- - - -)

which they unknowingly manipulate the crop microclimates (i.e. modifications on radiation, temperature, moisture and wind). Moreover, several studies indicate that the risk to the small-scale farmer in multiple cropping is lower than in sole cropping (Stigter and Weiss, 1986; Mukhala, 2000). The mechanisms of the microclimatic modification are, however, not scientifically clear. Therefore, this study has been initiated to clarify some of the microclimatic modifications in a maize-bean intercropping system, namely crop radiation interception and water use. The aim of this study is to assess the productivity of maize-bean intercropping in the region (Bloemfontein, Free State, South Africa, latitude $29^{\circ} \mathrm{S}$, longitude $26^{\circ} \mathrm{E}$ ), considering crop radiation and water utilisation.

\section{Materials and methods}

\section{Field trials}

Field experiments were conducted at the experimental sites of the Department of Soil, Crop and Climate Sciences, University of the Free State, during three summer growing seasons (1996/1997, 1998/1999 and 2000/2001), with variables in plant density, row orientation and sowing date trials, respectively (Mukhala, 1998; Tsubo, 2000; Ogindo, 2003). The agronomic information and the experimental treatments are shown in Table 1, and crop row arrangements of intercropping systems of maize and beans are shown in Fig.1. The plant density and row orientation experiments were carried out under non-stressed conditions of water, applying full irrigation, while the sowing date experiment was conducted under mainly rain-fed condition. All crops were planted by hand, and hand weeding was carried out in all plots throughout the growing seasons. The trials were arranged in a Randomised Com- 
plete Block Design with three or four replications. To determine radiation and water use, photosynthetically active radiation (PAR, 0.4 to $0.7 \mathrm{~mm}$ wavelength range) was measured above and beneath crop canopies, with single and linear quantum sensors (SunScan Canopy Analysis System, Delta-T Devices, Cambridge, UK; LI-190SB \& LI-191SA, LI-COR Inc., Lincoln, NE, USA). Soil water content was measured between 0 and $900 \mathrm{~mm}$ depth, with a neutron probe (Campbell Pacific Nuclear Model 530, Campbell Scientific Inc., Logan, UT, USA), and above-ground dry matter (AGDM) for each crop was measured periodically during the growing seasons.

\section{Climate and weather}

According to the Köppen climate classification, the climate of the study region belongs to Bsk (arid cold and dry climate, with mean annual temperature below $18^{\circ} \mathrm{C}$ ), and according to the Thornthwaite climate classification, it is categorised as a semi-arid warm climate (Schulze, 1947; Schulze and McGee, 1978). Figure 2 shows the long-term (30 years from 1961 to 1990) mean monthly temperature, rainfall and solar radiation in the study region (Bloemfontein Airport, South Africa, latitude $29^{\circ} 06^{\prime} \mathrm{S}$, longitude $26^{\circ} 18^{\prime} \mathrm{E}$, altitude $1351 \mathrm{~m}$ above sea level). The mean annual temperature is $15.9^{\circ} \mathrm{C}$, the annual rainfall is $559 \mathrm{~mm}$, and the mean annual global solar radiation is $244 \mathrm{~W} \mathrm{~m}^{-2}$. Moreover, the range between minimum and maximum temperatures is from $14.1^{\circ} \mathrm{C}$ in February to $32^{\circ} \mathrm{C}$ in January, $80 \%$ of rainfall occurs between November and April, and the ratio of diffuse to global solar radiation is maximum 0.3 in January and minimum 0.2 in June. Thus, summer of this region is characterised by a narrow range between maximum and minimum temperatures, high concentration of rainfall, and high fraction of diffuse solar radiation, contrasted to the winter season.

Temperature and rainfall data were recorded at the weather station of the Department of Soil, Crop and Climate Sciences, University of the Free State (latitude $29^{\circ} 06^{\prime} \mathrm{S}$, longitude $26^{\circ} 11^{\prime} \mathrm{E}$, altitude $1411 \mathrm{~m}$ above sea level) during the growing seasons. The monthly mean temperature and the monthly rainfall are shown in Table 2 . The seasonal mean temperature (November to April) was $19.3,21.0$ and $20.4^{\circ} \mathrm{C}$ for the 1996/1997, 1998/1999 and 2000/2001 growing seasons, respectively. Thus, the temperature for each growing season was not different from that for the long-term average value $\left(20.3^{\circ} \mathrm{C}\right)$. The seasonal rainfall (November to April) was 491, $301 \mathrm{~mm}$ and 328 $\mathrm{mm}$ for the 1996/1997, 1998/1999 and 2000/2001 growing seasons, respectively. The seasonal rainfall for the 1996/1997 growing season was $12 \%$ higher than the long-term value $(440 \mathrm{~mm}) . \mathrm{In}$ contrast, the seasonal rainfall was $32 \%$ and $25 \%$ lower in the 1998/ 1999 and 2000/2001 growing seasons, respectively.

\section{Results and discussion}

\section{Yield advantage}

Mass yields for maize kernels and bean seeds are shown in Table 3. In assessments of crop productivity of sole cropping systems, a useful expression is mass yield (mass per unit area). However, in intercropping systems, direct comparison is difficult
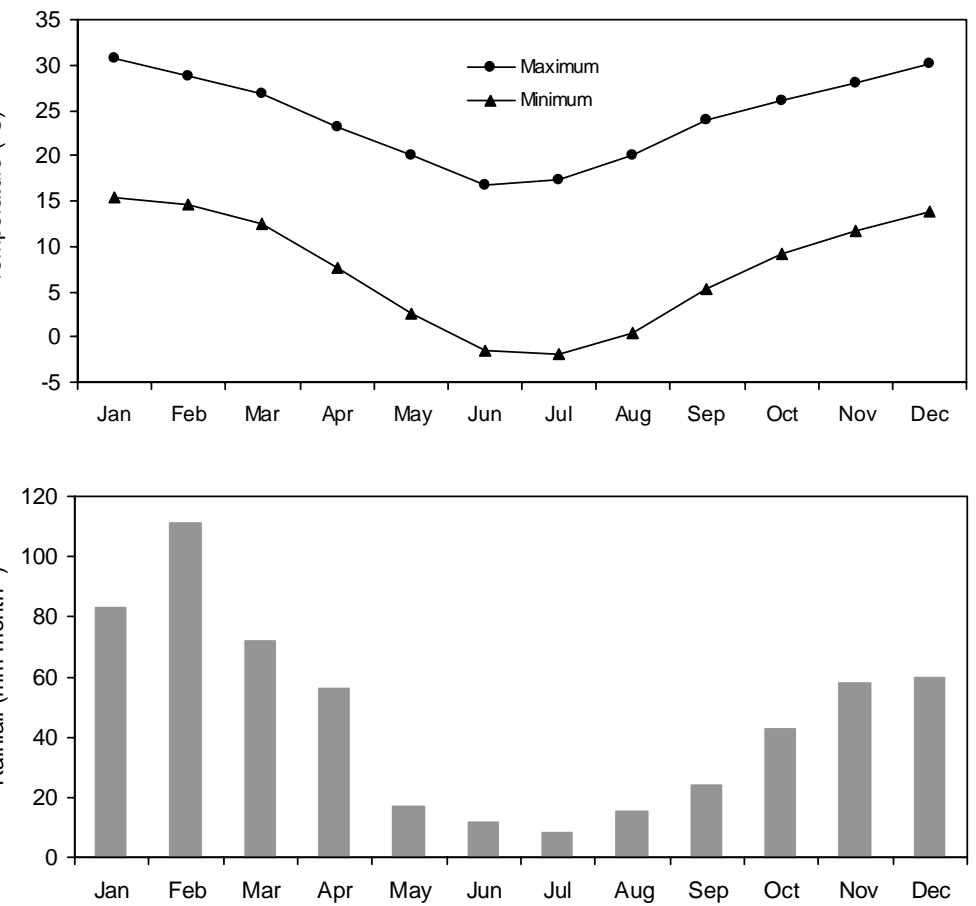

Jan Feb Mar Apr May Jun Jul Aug Sep Oct Nov Dec

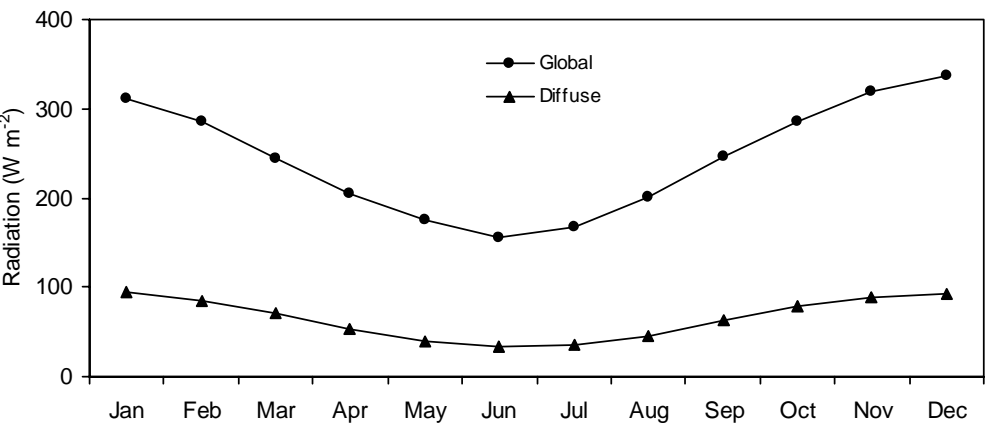

Figure 2

Long-term (30 years from 1961 to 1990) monthly weather data (temperature, rainfall and solar radiation) at Bloemfontein Airport, South Africa (2906'S, $\left.26^{\circ} 18^{\prime} \mathrm{E}, 1351 \mathrm{~m}\right)$.

because products are different for the different plant species growing on one piece of land (Beets, 1982). In this case, crop productivity should be evaluated using a common unit. A widely used method is the land equivalent ratio (LER) (Beets, 1982; Willey, 1985). LER is defined as the total land area required under mono-culture cropping to give the yields obtained in the polyculture cropping system (Mead and Willey, 1980). Total LER $\left(\mathrm{LER}_{\mathrm{T}}\right)$, including maize partial LER $\left(\mathrm{LER}_{\mathrm{M}}\right)$ and bean partial LER $\left(\operatorname{LER}_{\mathrm{B}}\right)$, was calculated as follows:

$$
\mathrm{LER}_{\mathrm{T}}=\mathrm{LER}_{\mathrm{M}}+\mathrm{LER}_{\mathrm{B}}=\mathrm{Y}_{\mathrm{IM}} / \mathrm{Y}_{\mathrm{SM}}+\mathrm{Y}_{\mathrm{IB}} / \mathrm{Y}_{\mathrm{SB}}
$$

where:

$\mathrm{Y}_{\mathrm{IM}}$ and $\mathrm{Y}_{\mathrm{IB}}$ are mass yields per unit area of intercropped maize kernels and bean seeds respectively, and

$\mathrm{Y}_{\mathrm{SM}}$ and $\mathrm{Y}_{\mathrm{SB}}$ are mass yields per unit area of sole cropped maize kernels and bean seeds respectively.

If $\mathrm{LER}_{\mathrm{T}}$ is greater than one ( $\mathrm{LER}_{\mathrm{T}}>1$ ), intercropping has a yield advantage while there is a yield disadvantage from intercropping if LER $_{\mathrm{T}}$ is less than one $\left(\mathrm{LER}_{\mathrm{T}}<1\right)$ (Beets, 1982; Willey, 1985).

A summary of LER values is shown in Table 4. In the row 


\begin{tabular}{|c|c|c|c|c|c|c|}
\hline \multicolumn{7}{|c|}{$\begin{array}{l}\text { TABLE } 2 \\
\text { Monthly mean temperature and monthly rainfall at the weather station of the University } \\
\text { of the Free State }\left(29^{\circ} 06^{\prime} \mathrm{S}, 26^{\circ} 11^{\prime} \mathrm{E}, 1411 \mathrm{~m}\right) \text { during the growing seasons }\end{array}$} \\
\hline & \multicolumn{6}{|c|}{ Month } \\
\hline & November & December & January & February & March & April \\
\hline $\begin{array}{l}\text { 1996/1997 growing season } \\
\text { Temperature }{ }^{\circ} \mathrm{C} \\
\text { Rainfall } \mathrm{mm} \cdot \mathrm{month}^{-1}\end{array}$ & $\begin{array}{c}18.1(-1.8) \\
112(+54)\end{array}$ & $\begin{array}{c}21.1(-0.9) \\
128(+68)\end{array}$ & $\begin{array}{c}21.6(-1.4) \\
67(-16)\end{array}$ & $\begin{array}{c}22.6(+0.8) \\
32(-79)\end{array}$ & $\begin{array}{c}19.1(-0.6) \\
122(+50)\end{array}$ & $\begin{array}{c}13.2(-2.2) \\
30(-26)\end{array}$ \\
\hline $\begin{array}{l}\text { 1998/1999 growing season } \\
\text { Temperature }{ }^{\circ} \mathrm{C} \\
\text { Rainfall } \mathrm{mm} \cdot \mathrm{month}^{-1}\end{array}$ & $\begin{array}{c}19.2(-0.7) \\
63(+5)\end{array}$ & $\begin{array}{c}21.3(-0.7) \\
51(-9)\end{array}$ & $\begin{array}{c}23.3(+0.3) \\
75(-8)\end{array}$ & $\begin{array}{c}22.1(+0.3) \\
56(-55)\end{array}$ & $\begin{array}{c}22.4(+2.7) \\
26(-46)\end{array}$ & $\begin{array}{c}17.7(+2.3) \\
30(-26)\end{array}$ \\
\hline $\begin{array}{l}\text { 2000/2001 growing season } \\
\text { Temperature }{ }^{\circ} \mathrm{C} \\
\text { Rainfall } \mathrm{mm} \cdot \mathrm{month}^{-1}\end{array}$ & $\begin{array}{l}18.9(-1.0) \\
7(-51)\end{array}$ & $\begin{array}{l}21.8(-0.2) \\
75(+15)\end{array}$ & $\begin{array}{l}22.8(+0.2) \\
33(-50)\end{array}$ & $\begin{array}{l}22.3(+0.5) \\
54(-57)\end{array}$ & $\begin{array}{l}21.2(+1.5) \\
58(-14)\end{array}$ & $\begin{array}{c}15.6(+0.2) \\
101(+45)\end{array}$ \\
\hline $\begin{array}{l}{ }^{\mathrm{a}} \text { Numbers in parentheses are } \\
\text { Bloemfontein Airport }\left(29^{\circ} 0\right.\end{array}$ & difference & om the long- & n (from 196 & 1990) mea & onthly data & \\
\hline
\end{tabular}

\begin{tabular}{|c|c|c|c|c|c|c|c|c|c|c|c|c|}
\hline \multicolumn{13}{|c|}{$\begin{array}{c}\text { TABLE } 3 \\
\text { Maize kernel and bean seed yields }\left(\mathrm{t} \cdot \mathrm{ha}^{-1}\right) \text { in sole cropping and intercropping systems }\end{array}$} \\
\hline & \multicolumn{6}{|c|}{ Maize } & \multicolumn{6}{|c|}{ Beans } \\
\hline & \multicolumn{3}{|c|}{ Sole cropping } & \multicolumn{3}{|c|}{ Intercropping } & \multicolumn{3}{|c|}{ Sole cropping } & \multicolumn{3}{|c|}{ Intercropping } \\
\hline \multirow{4}{*}{$\begin{array}{l}\text { Plant density trial }^{\mathrm{a}} \\
\quad(1996 / 1997) \\
\text { Row orientation trial } \\
(1998 / 1999)\end{array}$} & $\mathrm{L}$ & M & $\mathrm{H}$ & $\mathrm{L}$ & M & $\mathrm{H}$ & $\mathrm{L}$ & M & $\mathrm{H}$ & $\mathrm{L}$ & M & $\mathrm{H}$ \\
\hline & 7.9 & 9.0 & 10.3 & 6.0 & 8.3 & 9.0 & 2.8 & 4.4 & 5.4 & 1.2 & 1.5 & 1.5 \\
\hline & NS & & EW & NS & & EW & NS & & EW & NS & & EW \\
\hline & 8.5 & & 7.8 & 8.2 & & 7.8 & 4.2 & & 4.3 & 0.4 & & 0.4 \\
\hline \multirow{2}{*}{$\begin{array}{l}\text { Sowing date trialc } \\
\quad(2000 / 2001)\end{array}$} & $1^{\mathrm{st}}$ & & $2^{\text {nd }}$ & $1^{\mathrm{st}}$ & & $2^{\text {nd }}$ & $1^{\mathrm{st}}$ & & $2^{\text {nd }}$ & $1^{\text {st }}$ & & $2^{\text {nd }}$ \\
\hline & 2.5 & & 3.4 & 1.3 & & 1.7 & 1.7 & & 1.7 & 0.9 & & 1.9 \\
\hline $\begin{array}{l}{ }^{a} \text { L: low plant density; } \\
\text { b NS: north-south row } \\
{ }^{\mathrm{c}} 1^{\text {st: the first sowing d }}\end{array}$ & . & W & 11511 y & Dw & tat & & & & & & & \\
\hline
\end{tabular}

orientation trial, $\mathrm{LER}_{\mathrm{T}}$ for both north-south and east-west row treatments was greater than one, and there were no statistically significant differences between row orientations $(\mathrm{P}<0.05)$. On average, the intercropping had an $8 \%$ yield advantage over the sole cropping system in the row orientation trial. In other words, the sole cropping needed $8 \%$ more land to produce the same yield as with intercropping. The $\mathrm{LER}_{\mathrm{M}}$ was almost equivalent to one, while the $\mathrm{LER}_{\mathrm{B}}$ was around one-tenth. That is, the association of beans in the intercropping did not reduce the maize yield. However, the presence of maize in the intercropping reduced the yield of beans by $90 \%$ although the expected reduction was $50 \%$, because the plant density of intercropped beans was half of the population of sole beans. In this trial, the increase of the yield advantage was less than $10 \%$, indicating that the advantage of using intercropping was small.

In contrast, the higher $\mathrm{LER}_{\mathrm{T}}$ was obtained in the plant density trial (Table 4). As reported by Mukhala et al. (1999), yield advantages in maize-bean intercropping over the sole cropping were $17 \%, 26 \%$ and $15 \%$ for the low $\left(4.3\right.$ plants $\left.\mathrm{m}^{-2}\right)$, medium $(8.6$ plants $\cdot \mathrm{m}^{-2}$ ) and high plant densities (13.0 plants $\left.\cdot \mathrm{m}^{-2}\right)$, respectively, and the $\mathrm{LER}_{\mathrm{T}}$ of the medium plant density was significantly different from that of the other plant densities $(\mathrm{P}<0.05)$. The $\mathrm{LER}_{\mathrm{M}}$ increased from low to medium plant densities and decreased from medium to high plant densities, but the $\mathrm{LER}_{\mathrm{B}}$ consistently decreased with increase in maize plant density. The plant density trial $\operatorname{LER}_{B}(0.28)$ was more than double the row orientation trial $(0.10$ NS and $0.09 \mathrm{EW}$ ) at similar density. This could explain the higher yield advantages in the plant density trial. The differences in row arrangement (Fig. 1) might explain the difference of the intercropping yield advantage. This was because the density trial was planted in double bean alternate rows within the maize rows while the row orientation trial was planted as a single row alternate maizebean intercrop.

In the sowing date trial, $6 \%$ and $58 \%$ advantages for the first (planted 23 November 2000) and second (planted 11 January 2001) sowing dates, respectively, were obtained, and there was a statistically significant difference in $\mathrm{LER}_{\mathrm{T}}$ between treatments $(\mathrm{P}<0.05)$. The second sowing had about twice the $\mathrm{LER}_{\mathrm{B}}$, compared with the first sowing date, while the $\mathrm{LER}_{\mathrm{M}}$ for the first sowing date was equivalent to that for the second sowing data. From these results, the second sowing date treatment was more advantageous than the first sowing date. Because of serious water stress during 
the growing season, less advantage was found on the first sowing date. Compared with the other trials, the higher yield advantage for the second sowing date could result due to the design of the intercropping system. While the row orientation and plant density trials were conducted in a halfadditive design of intercropping, this trial was carried out in a full additive-design of intercropping. That is, in the former trials (the 1996/1997 and 1998/1999 growing seasons), half of the plant densities of bean sole cropping systems were added to full plant densities of maize sole cropping systems, while in the latter trial (the 2000/2001 growing season), the full plant density of bean sole cropping was intercropped in maize sole cropping. Since the expected LER $\mathrm{B}_{\mathrm{B}}$ was 0.5 for the half additive-design and 1.0 for the full additive-design, in the sowing date trial, high LER $_{\mathrm{T}}$ might result from the high poten-

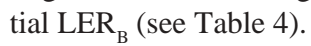

\section{Crop growth}

Seasonal changes in the ratio of dry matter of intercropping and sole cropping are presented in Table 5. The ratios for maize were around 0.69 for the plant density trial and 0.97 for the row orientation trial on average, so that the association of beans in the intercropping did not reduce maize dry matter in the row orientation trial, but did so in the plant density. In beans, the ratios were around 1.00 in the beginning of crop seasons in both trials and decreased to 0.69 for the plant density trial, and 0.33 for the row orientation trial, implying that the effect of maize crop association on bean dry matter was greater in the row orientation trial than in the plant density trial. In addition, there was little difference in the ratios for both maize and beans between experimental treatments (plant density for the 1996/1997 growing season and row orientation for the 1998/1999 growing season). In the sowing date trial, the ratios for both maize and beans were relatively constant. There was no difference in the ratios for maize between experimental treatments. However, for beans, the second sowing date had $50 \%$ higher ratios than the first sowing date. Like in the plant density trial, reduction in dry matter of maize associated with beans was
TABLE 4

The partial and total land equivalent ratio (LER) of maize and beans intercropping systems

\begin{tabular}{|c|c|c|c|c|c|c|c|c|c|}
\hline \multirow{3}{*}{ Row orientation trial ${ }^{\mathrm{a}}$} & \multicolumn{9}{|c|}{ LER } \\
\hline & \multicolumn{3}{|c|}{ Maize partial LER } & \multicolumn{3}{|c|}{ Bean partial LER } & \multicolumn{3}{|c|}{ Total LER } \\
\hline & NS & & EW & NS & & EW & NS & & EW \\
\hline$(1998 / 1999)$ & 0.96 & & 1.00 & 0.10 & & 0.09 & 1.06 & & 1.09 \\
\hline Plant density trial ${ }^{b}$ & $\mathrm{~L}$ & $\mathrm{M}$ & $\mathrm{H}$ & $\mathrm{L}$ & M & $\mathrm{H}$ & $\mathrm{L}$ & $\mathrm{M}$ & $\mathrm{H}$ \\
\hline$(1996 / 1997)$ & 0.76 & 0.92 & 0.87 & 0.41 & 0.34 & 0.28 & 1.17 & 1.26 & 1.15 \\
\hline Sowing date trial ${ }^{c}$ & $1^{\text {st }}$ & & $2^{\text {nd }}$ & $1^{\text {st }}$ & & $2^{\text {nd }}$ & $1^{\text {st }}$ & & $2^{\text {nd }}$ \\
\hline$(2000 / 2001)$ & 0.54 & & 0.49 & 0.52 & & 1.09 & 1.06 & & 1.58 \\
\hline
\end{tabular}

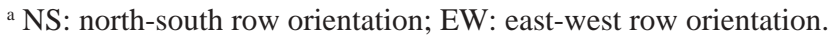

${ }^{\mathrm{b}} \mathrm{L}$ : low plant density; M: medium plant density; H: high plant density.

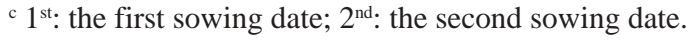

\begin{tabular}{|c|c|c|c|c|c|c|c|c|c|}
\hline \multicolumn{10}{|c|}{$\begin{array}{l}\text { TABLE } 5 \\
\begin{array}{c}\text { Seasonal changes in the ratio of dry matter }\left(g \cdot \text { plant }^{-1}\right) \text { of intercropping to } \\
\text { sole cropping }\end{array}\end{array}$} \\
\hline & \multicolumn{3}{|c|}{ Days after planting } & \multicolumn{3}{|c|}{ Maize } & \multicolumn{3}{|c|}{ Beans } \\
\hline $\begin{array}{l}\text { Plant density triala } \\
(1996 / 1997)\end{array}$ & $\mathrm{L}$ & $\begin{array}{c}M \\
35 \\
42 \\
52 \\
59 \\
66 \\
73 \\
80 \\
87 \\
94 \\
101 \\
115 \\
122 \\
129 \\
136\end{array}$ & $\mathrm{H}$ & $\begin{array}{c}\mathrm{L} \\
0.39 \\
0.89 \\
0.79 \\
0.65 \\
0.72 \\
0.79 \\
0.70 \\
0.73 \\
0.62 \\
0.76 \\
0.67 \\
0.79 \\
0.73 \\
0.77\end{array}$ & $\begin{array}{c}\mathrm{M} \\
0.51 \\
0.38 \\
0.43 \\
0.64 \\
0.63 \\
0.71 \\
0.60 \\
0.65 \\
0.68 \\
0.74 \\
0.67 \\
0.69 \\
0.75 \\
0.77\end{array}$ & $\begin{array}{c}\mathrm{H} \\
0.81 \\
0.82 \\
0.84 \\
0.79 \\
0.73 \\
0.77 \\
0.62 \\
0.68 \\
0.74 \\
0.96 \\
0.63 \\
0.66 \\
0.66 \\
0.57\end{array}$ & $\begin{array}{c}\mathrm{L} \\
0.83 \\
0.92 \\
0.65 \\
0.53 \\
0.48 \\
0.61 \\
0.82 \\
0.80 \\
0.72 \\
0.75 \\
- \\
- \\
- \\
-\end{array}$ & $\begin{array}{c}\mathrm{M} \\
1.23 \\
0.99 \\
0.61 \\
0.57 \\
0.84 \\
0.44 \\
0.91 \\
0.56 \\
0.59 \\
0.75 \\
- \\
- \\
- \\
-\end{array}$ & $\begin{array}{c}\mathrm{H} \\
1.26 \\
1.29 \\
0.69 \\
0.69 \\
0.79 \\
0.78 \\
0.83 \\
0.76 \\
0.60 \\
0.58 \\
- \\
- \\
- \\
-\end{array}$ \\
\hline $\begin{array}{c}\text { Row orientation trial } \\
(1998 / 1999)\end{array}$ & NS & $\begin{array}{c}28 \\
35 \\
42 \\
49 \\
56 \\
70 \\
84 \\
98 \\
112 \\
126\end{array}$ & EW & $\begin{array}{c}\mathrm{NS} \\
0.97 \\
1.03 \\
1.07 \\
1.04 \\
1.05 \\
1.02 \\
1.03 \\
0.98 \\
0.93 \\
0.90\end{array}$ & & $\begin{array}{l}\text { EW } \\
0.87 \\
1.01 \\
0.93 \\
0.96 \\
0.89 \\
0.93 \\
1.09 \\
0.88 \\
0.92 \\
0.87\end{array}$ & $\begin{array}{c}\text { NS } \\
0.93 \\
0.91 \\
0.54 \\
0.40 \\
0.39 \\
0.43 \\
0.34 \\
0.25 \\
0.25 \\
0.32\end{array}$ & & $\begin{array}{l}\text { EW } \\
1.00 \\
1.09 \\
0.53 \\
0.50 \\
0.40 \\
0.44 \\
0.36 \\
0.35 \\
0.28 \\
0.34\end{array}$ \\
\hline $\begin{array}{r}\text { Sowing date trial } \\
(2000 / 2001)\end{array}$ & $\begin{array}{c}1^{\text {st }} \\
21 \\
31 \\
42 \\
53 \\
101 \\
128\end{array}$ & & $\begin{array}{c}2^{\text {nd }} \\
24 \\
73 \\
98 \\
109 \\
- \\
-\end{array}$ & $\begin{array}{c}1^{\mathrm{st}} \\
0.66 \\
0.91 \\
0.85 \\
0.59 \\
0.80 \\
0.72\end{array}$ & & $\begin{array}{c}2^{\text {nd }} \\
0.57 \\
0.79 \\
0.88 \\
0.63 \\
- \\
-\end{array}$ & $\begin{array}{c}1^{\text {st }} \\
0.91 \\
0.63 \\
0.72 \\
0.77 \\
0.72 \\
0.85\end{array}$ & & $\begin{array}{c}2^{\text {nd }} \\
1.19 \\
0.98 \\
1.26 \\
1.15 \\
- \\
-\end{array}$ \\
\hline
\end{tabular}

found. Although dry matter of beans was reduced by maize association in the first sowing date treatment, no effect of maize association on bean dry matter was observed in the second sowing date treatment.

The ratios of dry matter of intercropping to sole cropping may correspond with the partial LER. So, adding the ratios for beans to 


\begin{tabular}{|c|c|c|c|c|c|c|c|c|c|}
\hline \multicolumn{10}{|c|}{ 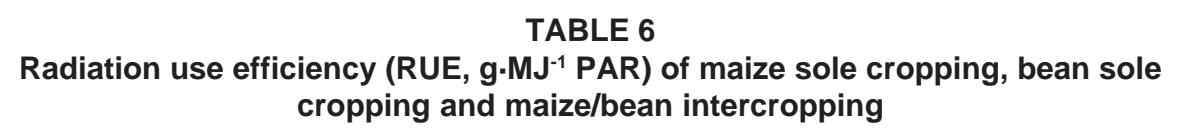 } \\
\hline & \multicolumn{9}{|c|}{ Cropping system } \\
\hline & \multicolumn{3}{|c|}{$\begin{array}{c}\text { Maize } \\
\text { sole cropping }\end{array}$} & \multicolumn{3}{|c|}{$\begin{array}{l}\text { Bean } \\
\text { sole cropping }\end{array}$} & \multicolumn{3}{|c|}{ Intercropping } \\
\hline \multirow{4}{*}{$\begin{array}{l}\text { Plant density trial }{ }^{\mathrm{a}} \\
\quad(1996 / 1997) \\
\text { Row orientation trial } \\
\quad(1998 / 1999)\end{array}$} & $\mathrm{L}$ & $\mathrm{M}$ & $\mathrm{H}$ & $\mathrm{L}$ & M & $\mathrm{H}$ & $\mathrm{L}$ & M & $\mathrm{H}$ \\
\hline & 2.26 & 2.80 & 2.82 & 0.98 & 1.00 & 1.00 & 2.40 & 2.82 & 3.18 \\
\hline & NS & & EW & NS & & EW & NS & & EW \\
\hline & 2.60 & & 2.56 & 1.56 & & 1.31 & 2.46 & & 2.41 \\
\hline \multirow{2}{*}{$\begin{array}{l}\text { Sowing date trial }{ }^{c} \\
\qquad(2000 / 2001)\end{array}$} & $1^{\text {st }}$ & & $2^{\text {nd }}$ & $1^{\text {st }}$ & & $2^{\text {nd }}$ & $1^{\mathrm{st}}$ & & $2^{\text {nd }}$ \\
\hline & 0.70 & & 2.85 & 0.30 & & 1.42 & 0.76 & & 3.63 \\
\hline
\end{tabular}

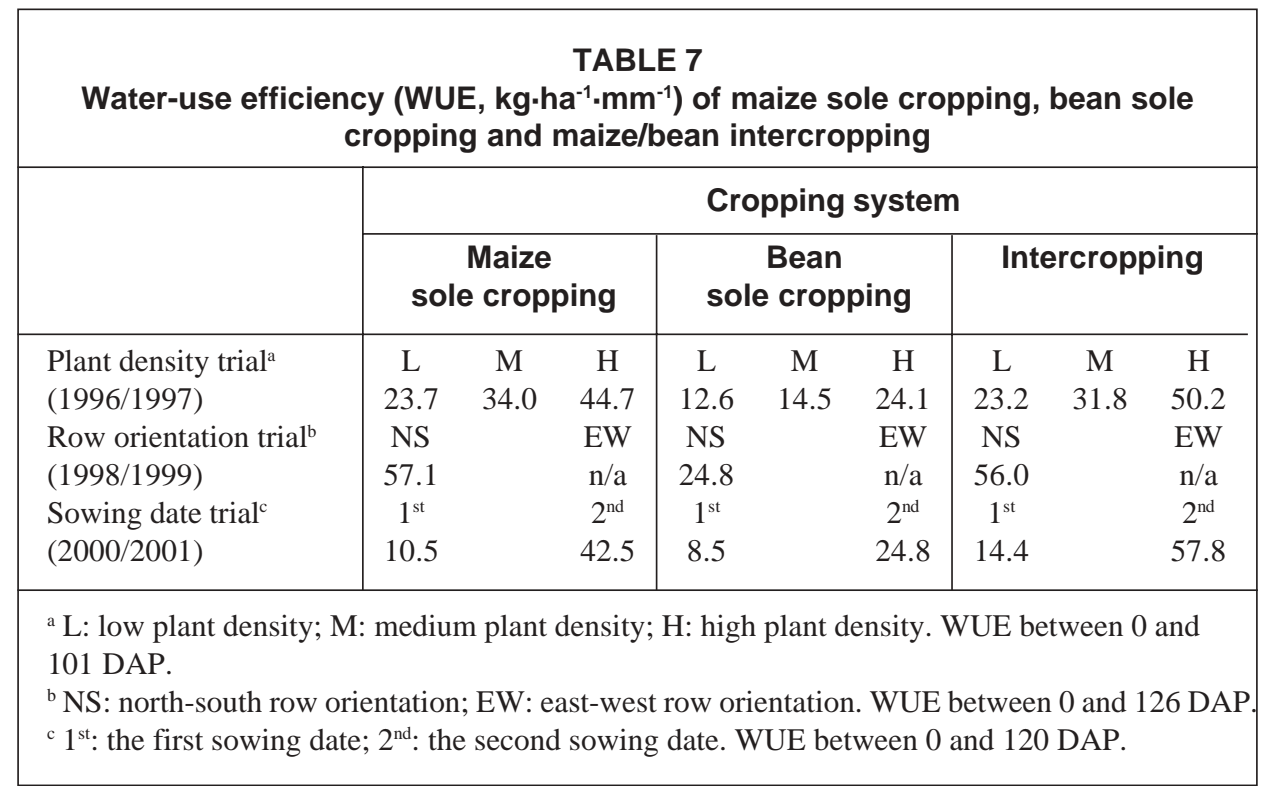

IPAR is the amount of PAR intercepted by crops, $\mathrm{F}$ is the fraction of PAR intercepted by crops, and $\mathrm{PAR}_{0}$ is incident PAR above crop canopies.

In this study, the sum of dry matter of maize and beans were used for calculating intercrop RUE because plant energy of maize is not different from that of beans (Tsubo et al., 2001).

Results of RUE for all trials are shown in Table 6. In comparing RUE among cropping systems, the intercropping had higher RUE than maize sole cropping at low and high plant density treatments and had similar RUE at medium plant density in the plant density trial. Similar results were obtained in both sowing date treatments in the sowing date trial. In the row orientation trial, maize sole cropping had slightly higher RUE than the intercropping in both row directions. Also, in all trials, RUE of bean sole cropping was the lowest of all cropping systems. In addition, the high density treatment in the plant density trial had greater RUE of maize sole cropping and the intercropping than the northsouth row treatment in the row orientation trial while bean sole cropping had higher RUE in the latter trial than in the former trial.

In comparing RUE among experimental treatments, the plant

the ratios for maize gives the LER for the growth advantage of intercropping. On average, the LER was 1.43 for the low density, 1.38 for the medium density and 1.56 for the high density in the plant density trial; 1.48 for the north-south row and 1.47 for the east-west row in the row orientation trial; 1.52 for the first sowing date and 1.86 for the second sowing date in the sowing date trial. Thus, in all cases, the intercropping had growth advantages. Hence, it was concluded that the intercrop yield advantages resulted from the growth advantages. This explains that final crop yield is influenced by crop growth; that is, good crop growth results in high crop yield. This concept has been shown clearly through this intercropping study.

\section{Radiation use efficiency}

Radiation use efficiency (RUE) was calculated as follows:

$$
\mathrm{RUE}=\mathrm{AGDM} / \mathrm{IPAR}=\mathrm{AGDM} /\left(\mathrm{F} \times \mathrm{PAR}_{0}\right)
$$

where: density trial showed that the higher plant density, the greater RUE in both maize sole cropping and the intercropping systems, whereas there was no difference in RUE of bean sole cropping. In the row orientation trial, RUE in north-south row orientation was slightly higher than that in east-west row orientation in all cropping systems. The second sowing date had greater RUE than the first sowing date in all cropping systems in the sowing date trial. All crops for the second sowing date were grown under less stressed conditions of water at the vegetative stages, compared with the first sowing date treatment. This might be the cause of the extremely low RUE values for the first sowing date treatment in all cropping systems. Similar results were reported by Muchow (1985) for legume crops and Inthapan and Fukai (1988) for cereal crops. Thus, soil water deficit could have a major negative effect on RUE (Sinclair and Muchow, 1999).

\section{Water-use efficiency}

The water balance equation was used to estimate water use by crops. Assuming no drainage and runoff water, water-use efficiency (WUE) was calculated as follows: 


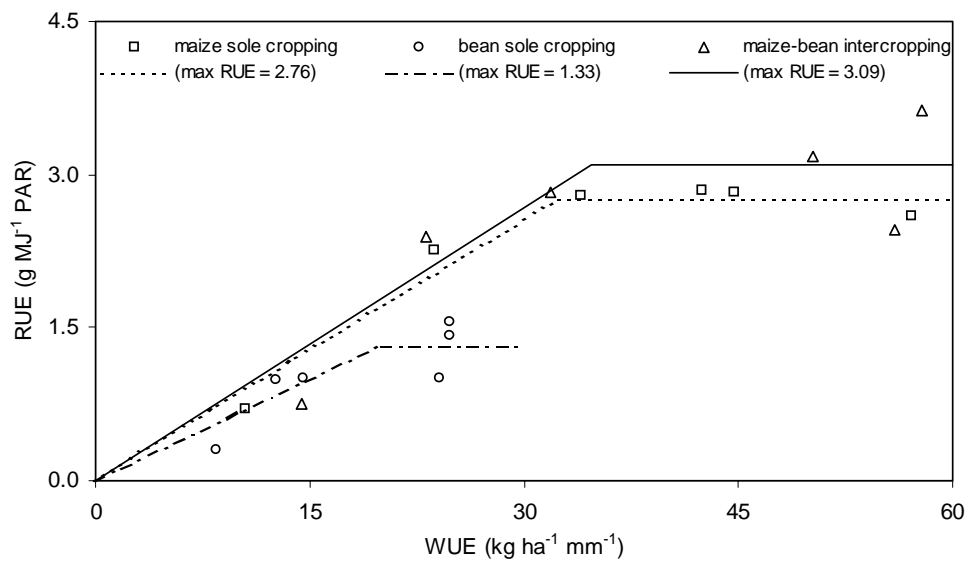

Figure 3

Relationships between radiation use efficiency (RUE) and water-use efficiency (WUE) of maize sole cropping, bean sole cropping and maize/ bean intercropping. Using six dates of RUE for each cropping system, the maximum RUE was calculated as the average of the three highest RUE of the data set while RUE between zero and the maximum value was determined as the slope of the linear regression of the three lowest RUE of the data set with the zero intercept.

$\mathrm{WUE}=\mathrm{AGDM} / \mathrm{ET}=\mathrm{AGDM} /(\mathrm{WA}-\Delta \mathrm{S})$

where:

ET is crop evapotranspiration,

WA is the amount of water applied to crops, including rainfall and irrigation water,

DS is the change in the amount of soil water in the root zone.

Similarly, intercrop WUE was calculated on the basis of total dry matter of maize and beans.

A summary of WUE for all trials is presented in Table 7. In the plant density trial, WUE increased as the plant density increased in all cropping systems. The intercropping $\left(50.2 \mathrm{~kg} \cdot \mathrm{ha}^{-1} \cdot \mathrm{mm}^{-1}\right)$ had greater WUE than maize sole cropping at the high plant density $\left(44.7 \mathrm{~kg} \cdot \mathrm{ha}^{-1} \cdot \mathrm{mm}^{-1}\right)$, sole maize $\left(34.0 \mathrm{~kg} \cdot \mathrm{ha}^{-1} \cdot \mathrm{mm}^{-1}\right)$ exhibited slightly higher WUE than the intercrop at medium plant density $(31.8$ $\left.\mathrm{kg} \cdot \mathrm{ha}^{-1} \cdot \mathrm{mm}^{-1}\right)$, and there was no difference in WUE between the intercropping $\left(23.3 \mathrm{~kg} \cdot \mathrm{ha}^{-1} \cdot \mathrm{mm}^{-1}\right)$ and maize sole cropping (23.7 $\mathrm{kg} \cdot \mathrm{ha}^{-1} \cdot \mathrm{mm}^{-1}$ ) at low plant density. WUE of the high plant density treatment was similar to that of the north-south row treatment (in the row orientation trial) in all cropping systems; there were similar plant densities between them. Bean sole cropping had comparatively lower WUE than the other cropping systems (maize sole cropping and the intercropping) in both plant density and row orientation trials.

In the sowing date trial, the intercropping WUE was higher than maize sole cropping WUE followed by bean sole cropping. The first sowing date treatment had $75 \%, 66 \%$ and $75 \%$ lower WUE for sole maize, sole beans and the intercrop, respectively, than the second sowing date treatment. The difference might be explained by soil water deficits, which was mentioned above. The distribution of rainfall during the growing season was poor in the first sowing date treatment, especially at the late vegetative stages. Thus, WUE is affected by the distribution of water application (Stanhill, 1986). Also, the second sowing date treatment had similar WUE to the higher density treatment and the north-south row treatment in all cropping systems, even though there was different plant densities between them.

\section{Relationships between radiation and water use}

Singh and Sri Rama (1989) reported a positive relationship between RUE of chickpea (Cicer arietinum) and extractable soil water content under stressed water conditions and constant RUE under conditions of non-stressed water. In this study, RUE was plotted against WUE, as shown in Fig. 3. In all cropping systems, RUE increased as WUE increased until the maximum RUE, and then RUE tended to be constant, which was probably explained by the photosynthetic process; i.e., the absorbed radiation is positively correlated with the transpired water until radiation saturation occurs. In other words, because high water requirement (= 1/WUE) means low WUE, RUE was lower under high water requirement (water deficit) than under low water requirement (water sufficiency), depicting that RUE is constant until water deficit starts, and then decreases. Although maize-bean intercropping had $12 \%$ higher maximum RUE than maize sole cropping, the trend line for the intercropping was analogous to that for maize sole cropping. Both maize sole cropping and intercropping were more than twice the maximum RUE of bean sole cropping. These relationships were positively correlated to yield and growth advantages of intercropping.

\section{Conclusions}

Many authors have reported that cereal-legume intercropping systems have higher productivity than sole cropping systems in various regions of Africa, including African semi-arid regions such as Eastern Africa (e.g. Fisher, 1977a; b; 1979; Pilbeam et al., 1994; Alemseged et al., 1996a; b) and Southern Africa (e.g. Rees, 1986a; b; c; Austin and Marais, 1987; Lightfoot and Tayler, 1987a; b). This study has presented the yield and growth advantages of maizebean intercropping in the study region, which is in basic agreement with previous studies in the other African regions. Concerning resource use, both RUE and WUE of maize-bean intercropping are equivalent to or higher than maize sole cropping, and they are higher in RUE and WUE than bean sole cropping. From those results, it follows that when farmers plan on cultivating both crops, planting maize associated with beans is more advantages than sole cropping. Maize-bean intercropping can thus be recommended to small-scale farmers in this semi-arid region. Also, plant density affects crop productivity and resource use of the intercropping while the effects of row orientation and sowing date are not clear.

In dryland crop production, the most limiting factor is water (rainfall and irrigation) availability, and it is thus necessary to improve crop water-use efficiency. The key can be found in reduced soil temperature and retained soil moisture. The solution may then lie in traditional cropping techniques, such as intercropping and mulching (Wilken, 1972; Baldy and Stigter, 1997). Intercropping is one of the types of mulching, often referred to as live mulching. Therefore, for understanding crop water use in cereallegume intercropping, evapotranspiration from legume crop canopies needs to be measured or estimated.

Net radiation (overall incoming and outgoing radiant energy at a surface) is the major contributor to energy balance. Within plant canopies, net radiation is of importance in describing the fundamental quantity of energy available for plant growth; that is, net 
radiation drives the processes of photosynthesis, evaporation, transpiration, and air and soil heating (Rosenberg et al., 1983). Net radiation comprises net short-wave solar radiation, which is utilised for assimilating carbon dioxide $\left(\mathrm{CO}_{2}\right)$ and net long-wave (thermal) radiation. With regard to crop water use, the most important phenomenon is that net radiation primarily provides the energy needed for evapotranspiration (Jensen et al., 1989). Therefore, studies on a radiation balance of the maize-bean intercropping as well as the energy balance need to be carried out.

Information that has been reported in this study may be valuable and helpful to agricultural scientists and extension officers with regard to on-farm advice for traditional cropping systems. This study has helped to rectify that situation by providing information on the radiation and water utilisation of maize and beans. However, the task to formulate a complete energy balance of the maize-bean intercropping still remains. It is interesting that shade manipulation by associated crops in intercropping may increase crop water use of dominant crops because of a reduction in evaporation from soil (Stigter and Weiss, 1986). Consequently, further micro-climatic studies on intercropping are essential to understand an explanation of its water-use efficiency.

\section{References}

ALEMSEGED YB, KING GW, COPPOCK LR and TOTHILL JC (1996a) A preliminary investigation of the potential for maize-legume intercropping in thee semi-arid area of Sidamo region, Ethiopia. I. Maize response. S. Afr. J. Plant Soil 13 120-124.

ALEMSEGED YB, KING GW, COPPOCK LR and TOTHILL JC (1996b) A preliminary investigation of the potential for maize-legume intercropping in the semi-arid area of Sidamo region, Ethiopia. II. Legume response. S. Afr. J. Plant Soil 13 125-130.

AUSTIN MN and MARAIS JN (1987) Methods of presenting intercropping results and preliminary results with Zea mays and Phaseolus vulgaris. S. Afr. J. Plant Soil 4 1-6.

BALDY C and STIGTER CJ (1997) Agrometeorology of Multiple Cropping in Warm Climates. INRA, Paris.

BEETS WC (1982) Multiple Cropping and Tropical Farming Systems. Westview Press, Boulder.

FAO (2000) The State of the Food Insecurity in the World 2000. FAO, Rome.

FISHER NM (1977a) Studies in mixed cropping. I. Seasonal differences in relative productivity of crop mixtures and pure stands in the Kenya highlands. Exp. Agric. 13 177-184.

FISHER NM (1977b) Studies in mixed cropping. II. Population pressures in maize-bean mixtures. Exp. Agric. 13 185-191.

FISHER NM (1979) Studies in mixed cropping. III. Further results with maize-bean mixtures. Exp. Agric. 15 49-58.

FRANCIS CA and ADIPALA E (1994) Tropical intercropping systems: What is their future? Afr. Crop Sci. J. 2 131-133.

INTHAPAN P and FUKAI S (1988) Growth and yield of rice cultivars under sprinkler irrigation in south-eastern Queensland. 2. Comparison with maize and grain sorghum under wet and dry conditions. Aust. J. Exp. Agric. 28 243-248.

JENSEN ME, BURMAN RD and ALLEN RG (1989) Evapotranspiration and Irrigation Water Requirements. American Society of Civil Engineers, New York.

LE HOUÉROU HN, POPOV GF and SEE L (1993) Agro-bioclimatic Classification of Africa. Agrometeorology. Series Working Paper No 6. FAO, Rome.

LIGHTFOOT CWF and TAYLER RS (1987a) Intercropping sorghum with cowpea in dryland farming systems in Botswana. I. Field experiments and relative advantages of intercropping. Exp. Agric. 23 425-434.

LIGHTFOOT CWF and TAYLER RS (1987b) Intercropping sorghum with cowpea in dryland farming systems in Botswana. II. Comparative stability of alternative cropping systems. Exp. Agric. 23 435-442.
MEAD R and WILLEY RW (1980) The concept of a 'land equivalent ratio' and advantages in yields from intercropping. Exp. Agric. 16 217-228.

MUCHOW RC (1985) An analysis of the effects of water deficits on grain legumes grown in semi-arid tropical environment in terms of radiation interception and its efficiency of use. Field Crops Res. 11 309-323.

MUKHALA E (1998) Radiation and Water Utilization Efficiency by Mono-Culture and Inter-Crop to Suit Small-Scale Irrigation Farming. Ph.D. Thesis, Univ. of the Orange Free State, Bloemfontein.

MUKHALA E (2000) An Evaluation of Communication Effectiveness Between Meteorological Scientists and Farmers in the Free State Province. M.A. Dissertation, Univ. of the Orange Free State, Bloemfontein.

MUKHALA E, DE JAGER JM, VAN RENSBURG LD and WALKER S (1999) Dietary nutrient deficiency in small-scale farming communities in South Africa: Benefits of intercropping maize (Zea mays) and beans (Phaseolus vulgaris). Nutr. Res. 19 629-641.

OFORI F and STERN WR (1987) Cereal-legume intercropping systems. Adv. Agron. 41 41-90.

OGINDO HO (2003). Comparing the Precipitation Use Efficiency of Maize-Bean Intercropping With Sole Cropping in a Semi-Arid Ecotope. Ph.D. Thesis, Univ. of the Free State, Bloemfontein.

PILBEAM CJ, OKALEBO JR, SIMMONDS LP and GATHUA KW (1994) Analysis of maize-common bean intercrops in semi-arid Kenya. J. Agric. Sci. Camb. 123 191-198.

REES DJ (1986a) Crop growth, development and yield in semi-arid conditions in Botswana. II. The effects of intercropping Sorghum bicolor with Vigna unguiculata. Exp. Agric. 22 169-177.

REES DJ (1986b) The effects of population density and intercropping with cowpea on the water use and growth of sorghum in semi-arid conditions in Botswana. Agric. For. Meteorol. 37 293-308.

REES DJ (1986c). The effects of population density, row spacing and intercropping on the interception and utilization of solar radiation by Sorgham bicolor and Vigna unguiculata in semi-arid conditions in Botswana. J. Appl. Ecol. 223 917-928.

ROSENBERG NJ, BLAD BL and VERMA SB (1983) Microclimate: The Biological Environment ( $2^{\text {nd }}$ edn.). John Wiley and Sons, New York.

SCHULZE BR (1947) The classification of South Africa according to the classifications of Köppen and Thornthwaite. S. Afr. Geog. J. 29 32-42.

SCHULZE BR and MCGEE OS (1978) Climatic indices and classification in relation to the biogeography of southern Africa. In: MJA Werger (ed.) Biogeography and Ecology of Southern Africa. Dr W. Junk Publishers, The Hague. 19-52.

SINCLAIR TR and MUCHOW RC (1999) Radiation use efficiency. Adv. Agron. 65 215-265.

SINGH P and SRI RAMA YV (1989) Influence of water deficit on transpiration and radiation use efficiency of chickpea (Cicer arietinum L.). Agric. For. Meteorol. 48 317-330.

STANHILL G (1986) Water-use efficiency. Adv. Agron. 39 53-85.

STIGTER CJ and WEISS A (1986) In quest of tropical micrometeorology for on-farm weather advisories. Agric. For. Meteorol. 36 289-296.

TSUBO M (2000) Radiation Interception and Use in a Maize and Bean Intercropping System. Ph.D. Thesis, Univ. of the Orange Free State, Bloemfontein.

TSUBO M, WALKER S and MUKHALA E (2001) Comparisons of radiation use efficiency of mono-/inter-cropping systems with different row orientations. Field Crops Res. 71 17-29.

VAN ROOYEN CJ and SIGWELE H (1998) Towards regional food security in southern Africa: a new policy framework for the agricultural sector. In: J van Rooyen, J Groenewald, S Ngqangweni and T Fényes (eds.) Agricultural Policy Reform in South Africa. Francolin Publishers, Cape Town. 262-282.

WILKEN GC (1972) Microclimate management by traditional farmers. Geogr. Rev. 62 544-560.

WILLEY RW (1985) Evaluation and presentation of intercropping advantages. Exp. Agric. 21 119-133.

WILLEY RW (1990) Resource use in intercropping systems. Agric. Water Manage. 17 215-231. 